\title{
A Literature Review and Directions FOR FUTURE RESEARCH ON INTERNATIONAL Student Perceptions of Online VERSUS FACE-TO-FACE EDUCATION: STUdent-CENTERED CHARACTERISTICS
}

\author{
Lynn A. Fish and Coral R. Snodgrass
}

Professors of Management

Richard J. Wehle School of Business

Canisius College

Email: fishl@canisius.edu

Email: snodgras@canisius.edu

Professor Fish is the corresponding author.

\begin{abstract}
As higher education institutions continue to integrate online education into their curricula, different cultural perspectives on the value of online versus face-to-face education will undoubtedly impact continued proliferation. Currently, some cultures are more accepting of online (Zhu et al., 2009; Lin et al., 2010), while others believe online education is inferior to traditional education (Asunka, 2008). Research on this topic has accelerated in the last
\end{abstract}


five years and primarily consists of cross-cultural comparisons. While research on student perceptions can be divided into 2 streams: student and program characteristics, the purpose of this study is to review the current literature with respect to student characteristics and offer suggested future directions for research. Perceptions are explored with respect to student characteristics of age, major/level, gender, previous online experience and student perceptions. The current literature has implications for today's administrators and instructors and offers researchers several avenues for continued research.

Keywords: International Student Perceptions, Online, Face-to-face

\section{LITERATURE REVIEW: DIMENSIONS OF DIFFERENCE}

The Babson Survey Research Group highlights the increase in online education throughout the higher education system (Allen \& Seaman, 2013). Academic administrators believe that learning outcomes through online education are the same or superior to those in traditional FTF classrooms (Allen \& Seaman, 2013); however, critics argue that due to intrinsic differences, online education does not replicate the learning that occurs in the traditional classroom (Bejerano, 2008). As online education continues to expand its horizons and technology continues to evolve, research on student perceptions in the online learning environment continues (e.g. Allen \& Seaman, 2013; Fish \& Snodgrass, 2014, 2015; Perreault, Waldman, Alexander \& Zhao, 2008; Tanner, Noser, and Langford, 2003; Tanner, Noser, Fuselier \& Totaro, 2004a; 2004b; Tanner, Noser, Totaro \& Birch, 2006; Tanner et al., 2009). Additionally, as online courses reach across borders, and based upon previous literature that suggests that foreign students have different needs than their Western classmates in faceto-face (FTF) classes (Selvarajah, 2006), students' cultural backgrounds affect their perception of the online learning environment (Popov et al., 2012). With this in mind, we present an overview of the literature on student perceptions of online versus FTF education with respect to cultural implications with a focus on the student-centered research. 
What do we know about cultural perceptions about online education now? Each culture has its own way of processing information, learning, instructing and solving problems (Lee, Becker \& Nobre, 2012). A nation's culture affects students' engagement, relations and perceived benefits from online education (Lee et al., 2012). There are differences in the manner in which people learn and different cultural learning models (Fang, 2007; Brislin et al., 1975; Jin, 2002; Charlesworth, 2008). Cultural backgrounds can differ in terms of cognitive styles, rules of behavior, communication styles, attitudes and belief systems as well as human relations (Hofstede, 1991). Cultural backgrounds present distinct challenges and opportunities to the growth of online education - particularly related differences in academic abilities, gender, perceptions of time, professional status, student expectations and tolerance for criticism (Chase et al., 2002).

Cultural differences impact upon student perceptions between online and FTF education and pose another potential barrier to online education (Grandon et al., 2005; Lin, Liu, Lee \& Magjuka, 2010; Olesova et al., 2011). Previous studies examined differences across cultures (Cronje, 2011; Chew \& Yee, 2015; Grandon et al., 2005; Li \& Kirkup, 2005; Popov et al., 2012, 2014; Zhu et al., 2009) and within cultures (Adler et al., 2001; Chase et al., 2002; Hamdan, 2014; Okwumabua et al., 2010). For example, in a recent cross-cultural comparison, U.S. students tend to work more independently than Chinese (Lin et al., 2010). While a study at a large, southeastern University in the U.S., both African-American and Caucasian American students' perceptions view online learning positively (Ashong \& Commander, 2012).

While some countries, such as China and India, appear to be attractive destinations for online education; world-wide acceptance of online learning is not evident. In some countries online education is perceived as second-rate to FTF education or believed to be purchased without assessment (Khoo and Azizan, 2004; Hamdan, 2014), and therefore, these countries enacted policies that do not recognize online degrees (Asunka, 


\section{The BRC Academy Journal of Education Vol. 5, No. 1}

2008; Kathawala et al., 2003; Hamdan, 2014). In many nations where education is different between men and women, such as east African nations, a lack of advancement in online education and a lack of research into how cultural factors may be impacted by online activity (Hamdan, 2014) may impact upon future growth and acceptance in these areas.

A study performed early in the century found that as students experienced more online learning, their attitudes toward online learning and blended approaches may change (Benbunan-Fich \& Hiltz, 2003; Karns, 2005). This shift in students' perceptions appears to be continuing. For example, while previous research indicated differences between Australians and Asian students in student perceptions (Ramburuth \& McCormick, 2001; Smith \& Smith, 1999), a more recent study (as noted previously) found no significant differences existed on many factors for these groups (Chew \& Yee, 2015). Another study reported on how Chinese students' motivation and learning strategies changed significantly towards a social-constructivist learning approach after an online collaborative experience (Zhu et al., 2009). Since many studies were performed over a decade ago, what are students' current perceptions regarding online versus FTF?

As education methods change to incorporate more online elements, educators and administrators need to understand these perceptual differences to be successful. Recent research noted the importance of instructor skills in teaching and called for instructors to gain a better, stronger understanding of the cultural and technological environment when designing learning activities (particularly discussion forums) (Chew \& Yee, 2015). Current research on students' perceptions can be divided into two streams of research: student-centered and program-centered. The amount of research in these areas has increased significantly in recent years, and in this paper we focus on the literature pertinent to student perceptions, specific student-centered characteristics and cultural implications between online and FTF. 
In a traditional FTF classroom, instructors recognize and react to student emotional states (facial expressions, gestures, eye contact and speech) and individual student differences (maturity and experience) to modify their lessons toward a positive learning environment (Reilly, Gallager-Lepak \& Killion, 2012). However, online instructors cannot perceive these factors in 'real' time and modify their responses instantly. These factors may impact upon students' attitudes and perceptions. Motivation, belief, confidence, computer anxiety, fear, boredom, apprehension, enthusiasm, pride and embarrassment (Konradt \& Sulz, 2001) are important antecedents of the student's inclination toward online learning (Chawla \& Joshi, 2012). Student-centered studies concentrate on differences between students' perceptions based upon demographic factors, such as age, academic level (undergraduate or graduate), gender, or previous experience (with the online environment), or by student perceptional characteristics, such as student motivation, discipline, self-directed learning, independence, and cost and time investment. Also, relevant to student perceptions are each student's personal preference, happiness, and appropriateness for the learning environment as well as potentially whether the student took an online preparation course. Cultural studies add another dimension. We continue by reviewing some of the literature with respect to culture, student characteristics (divided into demographic and perceptual sections) and online perceptions, and offer recommendations for future research within each subtopic.

\section{Student Characteristics: Demographic}

Age. Two streams of research exist with respect to age: one research stream demonstrates that age has a positive impact upon students' perceptions of online learning (Tanner et al., 2004-1; 2004-2), and another research stream that indicates age does not impact student perceptions (Tanner et al., 2003). One study found that adult students (21 and older) perceive online education more favorably than younger students (Tanner et al., 2003). Younger students, regardless of their culture, appear to be more technologically savvy and adaptable to different cultures (Lee et 
al., 2012). To our knowledge, age and cultural implications have not been fully explored, which leads to Research Questions \#1: Are younger cultures more inclined to accept online courses than older members? As people age, do they accept online courses more readily? Does the Millennial generation accept online education more willingly than Gen-Xers or Gen-Yers?

Major/ Level. Several studies explored perceptual differences by major and educational level with the majority of online studies since 2004 focusing on undergraduate students (Tsai \& Chiang, 2013). For example, cross-cultural researchers compared undergraduate students' perceptions between Dutch and International students (Popov et al., 2012), Malaysian and Australian freshman and sophomores (Chew \& Yee, 2015), Korean and American students (Grandon et al., 2005), and Flemish and Chinese students (Zhu et al., 2009). Graduate student perceptual studies explored Australian (Pillay \& James, 2014), Asian and European (Selvarajah, 2006), and South African and Sudanese (Cronje, 2011) perspectives. Additionally, one study evaluated the impact of online education on the culture and culture on online education in Saudi Arabia for undergraduate women (Hamdan, 2014). These studies appear to focus on one particular level - undergraduate or graduate, and a comparison between two cultures, which raises Research Question \#2a: Do undergraduates and graduates from different cultures perceive online and FTF learning environments differently?

Other studies, focused on the U.S., compare undergraduate and graduate perspectives for business versus non-business students (Tanner et al., 2004-1; 2004-2), business graduates and undergraduates (Fish \& Snodgrass, 2014), and graduate versus undergraduate nursing student (Billings, Skiba \& Connors, 2005). In our previous study, undergraduate and graduate business students did not differ with respect to their perception of online versus FTF environments for students and disliked the instructor interaction (Fish \& Snodgrass, 2014). Graduate business students tended to dislike the self-directed online environment slightly more than their undergraduate counterparts, and graduates were slightly more hesitant 
to accept online as a viable alternative to FTF. Graduate nursing students spent more time on their courses, needed more instructor attention and found faculty availability to be an issue compared to undergraduates. Since the majority of comparative studies focus on American students studying in the U.S., this prompts Research Question \#2b: Within each culture, do undergraduates and graduates perceive online and FTF learning environments differently?

Gender. With respect to gender differences, results differ with some studies indicating that gender does not play a factor in student perceptions for students (Fish \& Snodgrass, 2014; Tanner et al., 2003), while others indicate a difference (Tanner et al., 2004-1; 2004-2). Some research suggests that males are significantly more comfortable with computers (Kay, 2009) and Internet competencies are higher (Tekinarslan, 2011) than females. Other studies indicate that women experience a richer, more valuable presence in online learning and are more satisfied than males (Ashong \& Commander, 2012; Johnson, 2011). Regardless of culture, men tend to be more individualistic, while women tend to be collectivistic (Tsaw et al., 2011). (Individualistic people tend to be raised in Western cultures and focus on their own personal goals, while collectivistic people tend to be raised in Eastern cultures and focus on the group goals.) Gender issues can affect online learning as group composition, degree of participation and elaboration may differ by gender (with men using fewer words and less elaboration), and females are more likely to initiate conversation with questions and requests for information while males tend to explain and express disagreement more frequently (Prinsen et al., 2007). In one study of social loafing (whereby one group member does not contribute to group work fully or undermines the group work process), men displayed more social loafing than women (Tsaw et al., 2011). Comparing African-American perceptions to other American perceptions, women's perspectives are significantly different than men's as women view instructor assistance, friendliness, trust and interest in students, student interaction, and collaboration more positively than their male counterparts (Ashong \& Commander, 2012). Perhaps, nowhere 
in the world are gender issues more paramount than in societies that continue to separate men and women in the FTF - and online classroom, such as in Saudi Arabia (Hamdan, 2014). Differences around the world with respect to gender roles in society prompt educational questions as well, specifically Research Question\#3: Do men and women in other cultures (with different gender roles) perceive online education differently? Do women from male dominated cultures experience a cultural shift as in the Saudi Arabian study? Do men from male-dominated cultures differ in their perspective of online education than women?

Previous Experience. According to learning theory, the more someone is exposed and uses a particular method or technology, the better and more adept they become. Students with prior online experience perceived online courses more favorably than those without prior experience (Tanner et al., 2003). In criminal justice studies, students who have never taken an online course have different perceptions of online learning than those who have (Dobbs et al., 2009). However, in a study of business students - regardless of whether they took or did not take online courses, students favored FTF courses; however, most online respondents only took one course (Fish \& Snodgrass, 2014).

As the number of online courses increases, the students' acceptance of online courses increases as well; however, researcher found that at least 5 online courses are necessary for student to perceive that they learn more in the online environment than FTF (Dobbs et al., 2009). Selfefficacy, which is a student's belief in his or her own abilities to perform a given task in the online environment, and ease of use may be significant predictors for online learning (Grandon et al., 2005). Self-efficacy increases as a student's Internet usage frequency increases and is highly related to their prior computer and Internet experiences (Tekinarslan, 2011). Self-efficacy had an indirect impact upon perceived ease of use only for American students but not Koreans (Grandon et al., 2005).

While students without online experience perceive faculty as having low student expectations for students in online classes, students with 
online experience - especially as the number of online courses increases, perceive faculty as having higher expectations that increases with more experience (Dobbs et al., 2009). Studies evaluating student's perceptions of the continued proliferation of online courses demonstrate an increasing acceptance of online as being equal to or better than FTF (Mortagy \& Boghikian-Whitby, 2010; Perreault et al., 2008) particularly as students take more online courses (Dobbs et al., 2009; Mortagy \& BoghikianWhitby, 2010; Perreault et al., 2008). Similarly, our survey instrument indicated that as students take more courses, their perceptions of the online environment improved, and their perception that online courses were more difficult than traditional classes increased (Fish \& Snodgrass, 2014). Students modification of their perceptions over time, coupled with culture which lacks studies to test this effect, prompt Research Questions \#4: For different cultures, do students' perceptions change as they take additional online courses? Is ' 5 ' the 'magic number' between which students' perceptions between online and FTF shift from FTF to online preference?

\section{Student Characteristics: Perceptual Characteristics}

\section{Student Motivation, Discipline, Self-directed Learning and Inde-}

pendence. With the increase in online courses, understanding the factors that motivate students from different countries and cultures to take online courses is an important factor to consider (Grandon et al., 2005). In general, students are more motivated in courses when course content interests them and they find the material to be relevant (Adler et al., 2001). With regard to student motivation, results are mixed as some studies indicate that the online environment increases student motivation and self-esteem (Kearlsey, 1996) or increases critical thinking and work motivation (Larson \& Sung, 2009). Other studies indicate that the online environment offers low motivation for students to learn (Fish \& Snodgrass, 2014; Maltby \& Whittle, 2000) with retention issues (Abouchedid \& Eid, 2004; Carr, 2000) and low student satisfaction (Kenny, 2003; Muilenburg \& Berge, 2005). Individualistic students are more motivated to participate in online learning then collectivistic students (Tapanes et al., 
2009); however, in one study, Chinese students' motivation and learning strategies changed significantly towards a social-constructivist learning approach after an online collaborative experience (Zhu et al., 2009).

A more recent study indicates that students view e-learning as a commitment (Chawla \& Joshi, 2012). Online students should be motivated and disciplined (Schott et al., 2003) as students that are not self-motivated and committed will not enjoy the online learning environment (Rivera \& Rice, 2002). Online learning requires self-directed learning and autonomy, but self-discipline and motivation are also required to complete the course (Gifford, 1998; Kearsley, 2002). One study revealed that the Sudanese exhibited high levels of power distance towards their South African instructors but were reluctant to take responsibility for their own learning (Cronje, 2011). With online learning, students may feel an internal locus of control, which is the ability to exercise a degree of personal, internally-driven control over life decisions (Ohara, 2004). Saudi Arabian women experienced an increase in independence through online education as they had greater control over the learning process and discussed points of view and experienced different ways of thinking, different styles of writing and different approaches to improving their communication skills (Hamdan, 2014). Regardless of the environment, some students regard collaborative learning negatively and always prefer to work independently (Hiltz \& Turoff, 2005). Students' desires to work independently versus collectively differ by cultures as shown by a study comparing U.S. students who preferred independent work to Chinese students, who preferred group work (Lin et al., 2010).

The research presented here demonstrates a variety of student perceptions, which leads to the general research question: Research Question \#5: Do business students from different cultural backgrounds perceive motivation, self-directed learning, discipline and independence equally in the online and FTF learning environments?

Time and Cost Investment. On one hand, while students perceive the time flexibility to take the course (Chawla \& Joshi, 2012; Grandon 
et al., 2005), they perceive online learning to be more time consuming particularly with respect to class activities and homework assignments (Dobbs et al., 2009; Gifford, 1998; Perreault et al., 2008). Good time management skills are critical in online learning (Cheung \& Kan, 2002). Saudi Arabian women experienced an increase in time management through online education as they were able to plan their time better (Hamdan, 2014). Student beliefs regarding online include the overall experience, exposure and derived value (Chawla \& Joshi, 2012), which may also include the educational benefit and monetary cost associated with a course. Students who had never taken an online course indicated that they felt the value from an online course would be less than FTF (Chawla \& Joshi, 2012). In our study, online students were indifferent to time demands (Fish \& Snodgrass, 2014). These results prompt Research Question \#6: Do business students from different cultural backgrounds perceive the time and cost investments to online learning and FTF learning equally?

\section{Preference, Happiness and Appropriateness for Learning Envi-} ronment. While not intended to be a comprehensive review of literature in this area, clearly ambiguity currently exists in the debate between online and FTF education. Student satisfaction research with online versus FTF formats results are mixed as some studies indicate that the courses are equally effective across formats (Fowler, 2005; Horspool \& Lange, 2012; Topper, 2007), while others show a preference to FTF over online environments (Mullen \& Tallent-Runnels 2006), and others show a higher satisfaction for online learning (Connolly, MacArthur, Stansfield $\&$ McLelan, 2007). One study found that $10-20 \%$ of students always prefer FTF (Hiltz \& Turoff, 2005). In general, when students perceive e-learning as useful, they are more likely to accept and learn online (Tung \& Chang, 2008). In our literature review, a study that compared student perceptions between online and FTF across cultures for appropriateness is lacking. Research Questions \#7: Do students, regardless of their native culture, prefer the online or FTF learning environment? Are students from different cultural backgrounds happy in their learning environment? Do students 
from different cultural backgrounds feel that online learning is appropriate at the University?

Online Orientation. Online education requires students to believe in their own computer abilities, or self-efficacy. Orientation courses for students new to the online environment should be offered (Perreault Waldman, Alexander \& Zhao, 2002) as even students with technical expertise report benefits from an orientation program prior to their online experience (Clerkin, 2004). Initial studies on requirements for students prior to enrollment favored using training or tutorials (Perrault et al., 2002); however, more recent studies indicate that today's online students felt they are adequately prepared for online education without prior training (Perreault et al., 2008; Fish \& Snodgrass, 2014). Since student online perceptions are being sought in this study, student's previous background regarding orientations may be an important factor in their perspectives. Research Questions \#8: Regardless of culture, do students take online orientation courses prior to taking an online course? Given different cultures, what is the relationship between an online preparation course and student perceptions?

Cultural Student Differences. In addition to the demographic and perceptual characteristic differences between students, there are general differences in the way that different cultures address different student learning styles and requirements. For example, Chinese participants feel that they are less opinionated and critical than their U. S. counterparts (Thompson \& Ku, 2005). Added to these additional complexities, language competencies magnify cultural issues when completing an online course (Ku \& Lohr, 2003). Educational objective differences between cultures may be significantly different. For example, European and students of European backgrounds (such as New Zealanders) have different educational objectives to Chinese students (Selvarajah, 2006). Chinese students took courses to improve their standing with business associates (in support of reducing the power distance through education in a collectivist Confucianist culture (Bond \& Hofstede, 1998)), while New 
Zealanders took courses to improve individual skills for a potential career challenge and as a personal challenge (in supports of their individualist societies) (Selvarajah, 2006). Another cross-cultural study that compared US and South Korean students intentions to take online courses, American students chose to take online courses due to the perceived convenience, subjective norm ('social pressure to perform') and perceived ease of use, while Korean students chose to take online courses due to perceived quality and subjective norms (Grandon et al., 2005). Online assessment methods as they relate to the learning styles of a changing student population need to be considered (Selvarajah, 2006). In general, other research questions include Research Questions \#9: Does the nationality of a student impact upon his preferred learning environment? Does the nationality of a student impact upon his ability to learn online?

\section{DISCUSSION}

While the above literature review is not comprehensive, it highlights the different and mixed results that exist between and within cultures with respect to student characteristics and preferences for online education. This literature review demonstrates that each individual student with different cultural backgrounds may respond differently based upon their age, academic level, gender, and previous experience in the online environment. Clearly, culture impacts upon each student's perceived motivation, discipline, self-directed learning style, independence, and cost and time investment perspectives. Students' preferences for online and FTF vary as well as their happiness in one environment or the other. Given today's highly technological student body, students accept the online learning community (Fish \& Snodgrass, 2014). Several studies note that students' perceptions changed over time (Benbunan-Fich \& Hiltz, 203; Karns, 2005; Ramburuth \& McCormick, 2001; Smith \& Smith, 1999; Zhu et al., 2009), and recent research appears to indicate that the Millennials generation regards online education differently and are more accepting than Gen-Xers or Gen-Yers (Chew \& Yee, 2015). As online education continues to be 'borderless', instructors need to incorporate 


\section{The BRC Academy Journal of Education Vol. 5, No. 1}

design elements and activities to bridge these cultural gaps. This is a 'moving target' but needs guidance to foster student development - for all cultures. Therefore, as our research questions highlight, much work remains to uncover and guide instructors to address the diverse student body's needs in the online environment in order to meet each individual student's learning requirements.

\section{REFERENCES}

Abouchedid, K., \& Eid, G.M. (2004). E-learning challenges in the Arab World: Revelations from a case study profile. Quality Assurance in Education, 12(1), 15-27. http://dx.doi.org/10.1108/09684880410517405

Adler, R.W., Milne, M.J. \& Stablein, R. (2001). Situated motivation: an empirical test in an accounting course. Canadian fournal of Administrative Sciences, 18(2), 101-115. http://dx.doi.org/10.1111/j.1 936-4490.2001.tb00248.x

Allen, I., \& Seaman, J. (2013). Changing Course: Ten Years of Tracking Online Education in the United States. The Sloan Consortium (SloanC), Retrieved on January 11, 2013 from http://sloanconsortium.org/ publications/survey/making_the_grade_2006

Ashong, C.Y. \& Commander, N.E. (2012). Ethnicity, gender and perceptions of online learning in higher education. fournal of Online Learning and Teaching, 8(2), 98-110.

Asunka, S. (2008). Online Learning in Higher Education in Sub-Saharan Africa: Ghanaian University students' experiences and perceptions. International Review of Research in Open and Distance Learning, October 2008, 9(3), 1-23.

Benbunan-Fich, R. \& Hiltz, S.R. (2003). Mediators of effectiveness of online courses. IEEE Transactions on Professional Communication, 46(4), 2980312. http://dx.doi.org/10.1109/TPC.2003.819639

Bejerano, A.R. (2008). Raising the Question \#11 The Genesis and Evolution of Online Degree Programs: Who Are They For and What Have We 
Lost Along the Way? Communication Education, 57(3), 408-414. http:// dx.doi.org/10.1080/03634520801993697

Billings, D.M., Skiba, D.J. \& Connors, H.R. (2005). Best Practices in Webbased Courses: Generational Differences across Undergraduate and Graduate Nursing Students. Journal of Professional Nursing, 21(2), 126-133. http://dx.doi.org/10.1016/j.profnurs.2005.01.002

Bond, M.B. \& Hoefstede, G. (1988). Culture-level dimensions of social axioms and their correlates across 41 cultures. Journal of CrossCultural Psychology, 35(5), 548-570. http://dx.doi.org/10.1177/00220 22104268388

Brislin, R.W., Bochner, S. \& Lonner, W.J. (Eds) (1975). Cross-Cultural Perspectives on Learning, Sage Publications, Beverly Hills, CA.

Carr, S. (2000). As distance education comes of age, the challenge is keeping the students. Chronicle of Higher Education, 46(23), A39.

Charlesworth, Z.M. (2008). Learning styles across cultures: suggestion for educators. Education + Training, 50(2), 115-127. http://dx.doi.org/ 10.1108/00400910810862100

Chase, M. Macfayden, L., Reeder, K. \& Roche, J. (2002). Intercultural challenges in networked learning: hard technologies meet soft skills. First Monday, 7(8), http://dx.doi.org/10.5210/fm.v7i8.975

Chawla, D. \& Joshi, H. (2012). E-learning perception and its relationship with demographic variables: a factor analysis approach. International fournal of Information and Communication Technology Education, 8(4), 105-118. http://dx.doi.org/10.4018/jicte.2012100109

Chew, R. \& Yee, S. (2015). Perceptions of Online Learning in Australian University: Malaysian Students' Perspective - Support for Learning. International fournal of Information and Education Technology, 5(8), 587-592. http://dx.doi.org/10.7763/IJIET.2015.V5.573

Cheung, L. L., \& Kan, A. C. (2002). Evaluation of factors related to student performance in a distance-learning business communication course. Fournal of Education for Business, 77(5), 257-263. http://dx.doi.org/1 0.1080/08832320209599674

Clerkin, T. A. (2005). An exploratory study of the antecedents and consequences of relationships with executive search firms: Implications for a 
16 The BRC Academy Journal of Education Vol. 5, No. 1

model of career attainment.. Indiana University, ProQuest, UMI Dissertations Publishing, 2005. 3183914.

Connolly, T.M., MacArthur, E., Stansfield, M. \& McLellan, E. (2007). A quasi-experimental study of three online learning courses in computing. Computers \& Education, 49, 345-59. http://dx.doi.org/10 $.1016 / \mathrm{j}$. compedu.2005.09.001

Cronje, J. (2011). Using Hofstede's cultural dimensions to interpret crosscultural blended teaching and learning. Computers \& Education, 56, 596-603. http://dx.doi.org/10.1016/j.compedu.2010.09.021

Dobbs, R., Waid, C.A., \& del Carmen, A. (2009). Students' Perceptions of Online Courses: The Effect of Online Course Experience. Quarterly Review of Distance Education, Spring 2009, 10(1), 9-26.

Fang, L. (2007). Perceiving the useful, enjoyable and effective: a case study of the e-learning experience of tertiary students in Singapore. Educational Media International, 44(3), 237-253. http://dx.doi.org/10 .1080/09523980701491682

Fish, L.A. \& Snodgrass, C.R. (2014). A Preliminary Study of Business Student Perceptions of Online versus Face-to-Face Education. BRC Fournal of Advances in Education, pp. 1-21. DOI: http://dx.doi.org/1 0.15239/j.brcacadje.2014.04.01.ja01

Fish, L.A. \& Snodgrass, C.R. (2015). A preliminary study of international student perceptions of online versus face-to-face education. BRC Academy fournal of Business, 5, 1, pp. 67-99. Print ISSN: 2152-8721 Online ISSN: 2152-873X http://dx.doi.org/10.15239/j.brcacadjb.2015 .04 .01

Fowler, D. (2005). Are on-site courses as effective as online? Online Cl@ssroom: Ideas for Effective Online Instruction, March, 1-2.

Gifford, L. (1998). Graduate Students' Perceptions of Time Spent in Taking a Course by Internet versus Take a Course in a Regular Classroom. Annual Mid-South Educational Research Association Conference, New Orleans, LA, Nov. 4-6, 1998, 1-10.

Grandon, E.E., Alshare, K. \& Kwun, O. (205). Factors Influencing Student Intention to Adopt Online Classes: A Cross-Cultural Study. Consortium for Computing Sciences in Colleges, 46-56. 
Hamdan, A. (2014). The Reciprocal and Correlative Relationship Between Learning Culture and Online Education: A Case from Saudi Arabia. The International Review of Research in Open and Distance Learning. 15(1), 309-336.

Hiltz, S. R., \& Turoff, M. (2005). Education goes digital: The evolution of online learning and the revolution in higher education. Communications of the ACM, 48(10), 59-64. doi:10.1145/1089107.1089139

Hofstede, G. (1991). Cultures and organizations: Software of the mind. London: McGraw-Hill.

Horspool, A. \& Lange, C. (2012) Applying the scholarship of teaching and learning: student perceptions, behaviors and success online and face-to-face, Assessment \& Evaluation in Higher Education, February 2012, 37(1), 73-88. http://dx.doi.org/10.1080/02602938.2010.496532.

Jin, L. (2002). Learning models in different cultures. New Directions for Child and Adolescent Development, 2002(96), 45-64. http://dx.doi.org/ 10.1002/cd.43

Johnson, R.D. (2011). Gender differences in e-learning: Communication, social presence, and learning outcomes. Fournal of Organizational and End User Computing, 23(1), 79-94. http://dx.doi.org/10.4018/joeuc. 2011010105

Karns, G.L. (2005). An Update of Marketing Student Perceptions of Learning Activities: Structure, Preferences, and Effectiveness. fournal of Marketing Education, 27(2), 163-171. http://dx.doi.org/10.1177/02 73475305276641

Kathawala, Y., Abdou, K., \& Elmulti, D. S. (2003). The global MBA: A comparative assessment for its future. Fournal of European Industrial Training, 26(1), 14-23. http://dx.doi.org/10.1108/03090590210415867

Kay, R.H. (2009). Examining gender differences in attitudes toward interactive classroom communication systems (ICCS). Computers \& Education, 52(4), 730-740. http://dx.doi.org/10.1016/j.compedu.2008. 11.015

Kearsley, G. (2002). Learning and teaching in cyberspace. Belmont, CA: Wadsworth. 
Kenny, J. (2003). Student perceptions of the use of online learning technology in their courses. ultiBASE Articles. Accessed on January 9, 2013 from http://ultibase.rmit.edu.au/Articles/march03/kenny2.pdf

Khoo, J., \&Azizan, H. (2004). Pitfalls of paper chase. Star Education, 2-4.

Kim, K., Liu, S., \& Bonk, C. (2005). Online MBA students' perceptions of online learning: Benefits, challenges, and suggestions. Internet and Higher Education, 8, 33-35. http://dx.doi.org/10.1016/j.iheduc.2 005.09.005

Konradt, U., \& Sulz, K. (2001). The experience of flow in interacting with a hypermedia learning environment. fournal of Educational Multimedia and Hypermedia, 10(1), 69-84.

Ku, H. \& Lohr, L. L. (2003). A case study of Chinese students' attitude toward their first online learning experience. Education Technology Research and Development,51(3), 94-102. http://dx.doi.org/10.1007/ BF02504557

Larson, K., \& Sung, C, (2009). Comparing Student Performance: Online Versus Blended Versus Face-To-Face, fournal of Asynchronous Learning Networks, 13(1), 31-42.

Lee, J.W., Becker, K. \& Nobre, H. (2012). Impact of culture on online management education. Cross Cultural Management, 19(3), 399-420. http://dx.doi.org/10.1108/13527601211247116

Li, N. \& Kirkup, G. (2005). Gender and cultural differences in internet use: a study of China and the UK. Computers \& Education, 48, 301-317. http://dx.doi.org/10.1016/j.compedu.2005.01.007

Lin, X,.Liu, S., Lee, S. \& Magjuka, R.J. (2010). Cultural Differences in Online Learning: International Student Perceptions. Educational Technology \& Society, 13(3), 177-188.

Maltby, J. R., \& Whittle, J. (2000). Learning programming online: Student perceptions and performance. Proceedings of the ASCILITE 2000 Conference. Accessed on January 9, 2013 from http://www.ascilite. org.au/conferences/coffs00/papers/john_maltby.pdf 
Mortagy, Y. \& Boghikian-Whitby, S. (2010). A Longitudinal Comparative Study of Student Perceptions in Online Education. Interdisciplinary fournal of E-Learning and Learning Objects, 6, 23-46.

Muilenburg, L. Y . \& Berge, Z.L. (2005). Student barriers to online learning: A factor analytic study. Distance Education, 26(1), 29-48. http://dx. doi.org/10.1080/01587910500081269

Mullen, G.E., \& Tallent-Runnels, M.K. (2006). Student outcomes and perceptions of instructors' demands and support in online and traditional classrooms. Internet and Higher Education, 9, 257-66. http:// dx.doi.org/10.1016/j.iheduc.2006.08.005

Ohara, M. (2004). Maximizing e-learning ROI: Identifying successful online learners. Allied Academies International Conference, 8(1), 49-54.

Okwumabua, T. M., Walker, K.M., Hu, X. \& Watson, A. (2010). An exploration of African American students' attitudes toward online learning. Urban Education, 46(2), 241-250. http://dx.doi.org/10.1177 /0042085910377516

Olesova, L., Yang, D. \& Richardson, J.C. (2011). Cross-cultural differences in Undergraduate Students' Perceptions of Online Barriers. Fournal of Asynchronous Learning Networks, 15(3), 68-80.

Perreault, H., Waldman, L., Alexander, M. \& Zhao, J. (2008). Graduate Business Students' Perceptions of Online Learning: A Five Year Comparison. The Delta Pi Epsilon fournal,Fall 2008, L(3), 164-179.

Perreault, H., Waldman, L., Alexander, M. \& Zhao, J. (2002). Overcoming barriers to successful delivery of distance-learning courses. Fournal of Education for Business, 77(6), 313-318. http://dx.doi.org/10.1080/0 8832320209599681

Pillay, S. \& James, R. (2014). The pains and gains of blended learning social constructivist perspectives. Education + Training, 56(4), 254-270. http://dx.doi.org/10.1108/ET-11-2012-0118

Popov, V., Brinkman, D., Biemans, H.J.A., Mulder, M. Kuznetsov, A. \& Noroozi, O. (2012). Multicultural student group work in higher education: a study on challenges as perceived by students. International fournal of Intercultural Relations, 36(2), 302-317. http://dx.doi.org/1 0.1016/j.ijintrel.2011.09.004 
Popov, V., Noroozi, O., Barrett, J.B., Biemans, H.J.A., Teasley, S.D., Slof, B. \& Mulder, M. (2014). Perceptions and experiences of, and outcomes for, university students in culturally diversified dyads in a computersupported collaborative learning environment. Computers in Human Behavior, 32, 186-200. http://dx.doi.org/10.1016/j.chb.2013.12.008

Prinsen, F.R., Volman, M.L.L. \& Terwel, J. (2007), Gender-related differences in computer-mediated communication and computersupported collaborative learning. Fournal of Computer Assisted Learning, 23(5), 393-409. http://dx.doi.org/10.1111/j.1365-2729.2007. 00224.x

Ramburuth, P. \& McCormick, J. (2001). Learning diversity in higher education: A comparative study of Asian international and Australian students. Higher Education, 42(3), 333-350. http://dx.doi.org/10.1023 /A:1017982716482

Reilly, J.R., Gallager-Lepak, S. \& Killion, C. (2012). Me and My Computer: Emotional Factors in Online Learning, Nursing Education Perspectives, March/April, 33(2), 100 - 105.

Rivera, J. C., \& Rice, M. L. (2002). A comparison of student outcomes and satisfaction between traditional and web based course offerings. Online fournal of Distance Learning Administration, 5(3).

Schott, M., Chernish, W., Dooley, K. E., \& Linder, J. R. (2003). Innovations in distance learning program development and delivery. Online fournal of Distance Learning Administration, 6(2).

Selvarajah, C. (2006). Cross-cultural study of Asian and European student perception. Cross-Cultural Management, 13(2), 142-155. http://dx.doi. org/10.1108/13527600610662320

Smith, P.J. \& Smith, S.N. (1999). Differences between Chinese and Australian students: Some implications for distance education. Distance Education, 20(1), 64-75. http://dx.doi.org/10.1080/0158791990200106

Tanner, J.R., Noser, T.C., \& Totaro, M.W. (2009). Business Faculty and Undergraduate Students' Perceptions of Online Learning: A Comparative Study. Journal of Information Systems Education, Spring 2009, 20(1), 29-40. 
Tanner, J., Noser, T., Totaro, M., \& Birch, R. (2006). Student Perceptions of The Online 'Classroom': An Update. International Business \& Economics Research fournal, 5(10), 31-38.

Tanner, J., Noser, T., Fuselier, J., \& Totaro, M. (2004-1). 'The Online 'Classroom': Differences in Perception between Business Students and Non-Business Students. fournal of College Teaching and Learning, 1(3), 37-44.

Tanner, J., Noser, T., Fuselier, J., \& Totaro, M. (2004-2), 'The Online 'Classroom': What Do Students Think? Journal of Informatics Education Research, 6 (1), 43-54.

Tanner, J., Noser, T., \& Langford, H. (2003). Perceptions of Undergraduate Business Students Toward Online Courses In Higher Education Expanded and Revisited: Do Gender, Age, and/or Past Experiences Make a Difference? Journal of Business and Economics Research, 1(2), 13-20.

Tapanes, M.A., Smith, G.G. \& White, J.A. (2009). Cultural diversity in online learning: A study of the perceived effects of dissonance in levels of individualism/collectivism and tolerance of ambiguity. The Internet and Higher Education, 12, 26-34. http://dx.doi.org/10.1016/j. iheduc.2008.12.001

Tekinarslan, E. (2011). Faculty of Education Students' Self-efficacy Perceptions toward Online Technologies. Electronic fournal of Social Sciences, Summer 2011, 10(37), 120-134.

Thompson, L. \& Ku, H. (2005). Chinese graduate students' experiences and attitudes toward online learning. Educational Media International, 42(1), 33-47. http://dx.doi.org/10.1080/09523980500116878

Topper, A. (2007). Are they the same? Comparing the instructional quality of online and face-to-face graduate education courses. Assessment \& Evaluation in Higher Education, 32 (6), 681-691. http://dx.doi.org/1 $0.1080 / 02602930601117233$

Tsai, C.W. \& Chiang, Y.C.(2013). Research trends in problembased learning (PBL) research in e-learning and online education environments: A review of publications in SSCI0indexed journals 
22 The BRC Academy Journal of Education Vol. 5, No. 1

from 2004 to 2012. British Journal of Educational Technology, 44(6), E185-E190. http://dx.doi.org/10.1111/bjet.12038

Tsaw, D., Murphy, S., Detgen, J. (2011). Social loafing and culture: Does gender matter? International Review of Business Research Papers, 7(3), 1-8.

Tung, F. C., \& Chang, S. C. (2008). An empirical investigation of students' behavioral intentions to use the online learning course websites. British fournal of Educational Technology, 39(1), 71-83.

Zhu, C. Valcke, M. \& Schellens, T. (2009). A cross-cultural study of online collaborative learning. Multicultural Education and Technology fournal, 3(1), 33-46. http://dx.doi.org/10.1108/17504970910951138।

\section{Citation Information}

Fish, Lynn A., and Coral R. Snodgrass. "A Literature Review and Directions for Future Research on International Student Perceptions of Online versus Face-to-Face Education: Student-centered Characteristics." The BRC Academy fournal of Education 5, no. 1 (2016): 1-22. http:// dx.doi.org/10.15239/j.brcacadje.2016.05.01.ja01 